\title{
PRODUCTION OF PALM-BASED GLYCOL ESTER VIA AUTOCATALYTIC ESTERIFICATION
}

\author{
NOOR AZEERAH ABAS*; ROZITA YUSOFF*; HALIZA ABDUL AZIZ* and ZAINAB IDRIS*
}

\begin{abstract}
The self-esterification of the lauric acid (LA) with diethylene glycol (DEG) to produce diethylene glycol dilaurate (DEG-DL) was conducted under atmospheric via conventional method. The effects of reaction temperature, reactant molar ratio and stirring speed rate were studied. Results showed that the composition of DEG-DL was increased with the increase in reaction temperature and reactant molar ratio. The reaction rate was observed independent of stirring speed rate. A high conversion of $L A(>90 \%)$ was obtained based on one-factor-at-time (OFAT) method of designing experiments. At the reaction temperature of $230^{\circ} \mathrm{C}$ and molar ratio of $L A$ : DEG was varied from 1:1 to 2:1, the composition of DEG-DL was increased from $50.1 \%$ to $97.2 \%$. Nuclear magnetic resonance (NMR) spectra confirmed a compound produced was DEG-DL based on structural result. The acid value of $\mathrm{LA}$ was reduced from 182 to $3.09 \mathrm{mg} \mathrm{KOH} \mathrm{g-1} \mathrm{LA}$. The autocatalytic esterification is a clean reaction as it omits the separation step of catalyst and solvents. The hydrophilic lipophilic balance (HLB) index calculated for DEG-DL was 7.5 and potentially functioned as a water-in-oil or oil-in-water emulsifier for cosmetic applications.
\end{abstract}

Keywords: palm-based glycol ester, surfactant, clean process, HLB index.

Date received: 8 January 2019; Sent for revision: 9 January 2019; Accepted: 5 July 2019.

\section{INTRODUCTION}

Malaysia is blessed with the abundant supply of palm oil and palm kernel oil. In 2017 alone, a total of 5.81 million hectares of land were planted with oil palm which produced an average yield of fresh fruit bunch (FFB) of $17.89 \mathrm{t} \mathrm{ha}^{-1}$. Subsequently, the oil palm fruitlets yield 3.53 tha $^{-1}$ of crude palm oil (CPO) from the mesocarp and $0.88 \mathrm{t} \mathrm{ha}^{-1}$ of palm kernel oil (PKO) from the kernel seed (Kushairi et al., 2018). Today, oleochemical industries market in Malaysia accounted for $20 \%$ of world's basic oleochemical capacity. The industry emerged rapidly as 2.76 million tonnes of oleochemicals are exported to Europe and this contributed to additional revenue over the basic value of the commodity oils (Razmah, 2017).

\footnotetext{
* Malaysian Palm Oil Board,

6 Persiaran Institusi, Bandar Baru Bangi,

43000 Kajang, Selangor, Malaysia.

E-mail: noorazeerah.abas@mpob.gov.my

** Department of Chemical Engineering,

Faculty of Engineering,

Universiti Malaya,

50603 Kuala Lumpur, Malaysia.
}

Esters are derived by the reaction of a carboxylic acid and an alcohol with water as a by-product (Kantlehner, 1991). Direct esterification can be catalysed or even can proceed in a spontaneous fashion, depending on the reactants properties, the temperature and the acidity of the carboxylic acid reaction partner to produce esters (Hans et al., 2004). Conventionally, the esterification process is performed in the presence of either homogeneous or heterogeneous catalyst. However, there were some drawbacks on the use of homogeneous acid catalyst (Zhong et al., 2015). Strong mineral acids may form toxic and carcinogen esters with the alcohols, if the reactions were conducted at very high temperatures and some issue related to corrosion and separation problems.

It is difficult to separate the catalyst in the product mixture and that requires additional steps of purification in order to produce product with high purity (Mazo et al., 2012). The carbon chain length of carboxylic acid, the alcohol feedstock, the reaction temperature and the design of the reactor system are parameters influencing the conversion of fatty acid (Kalaru et al., 2009). 
The incorporation of biocatalyst (enzyme) as heterogeneous catalyst in esterification consumes less energy than chemical process, produces a clean ester with excellent properties, biodegradable and low toxicity (Jothiramalingam and Wang, 2009). Nevertheless, enzymatic reactions are quite difficult to handle because they are highly sensitive to changes in physical and chemical conditions surrounding them. Besides, the biocatalyst is easily denatured by even a small increase in temperature and is highly susceptible to poisons and changes in $\mathrm{pH}$. Another drawback of this type of heterogeneous catalyst is the high cost of enzyme isolation and purification that discourages their use (Robert, 1997).

Hence, to minimise on the use of catalyst in order to produce green and clean palm-based glycol ester, the self-esterification process was proposed subsequently to develop the standard esterification protocol. There were few studies published on both esterification reactions in the absence of catalyst that result in simple purification, clean and green processes (Yujaroen et al., 2009; Yamazaki et al., 2007; Maeda et al., 2008).

Hyun et al. (2012) conducted autocatalytic esterification of palm fatty acid distillate (PFAD) with methanol at high temperature in order to obtain acid value less than $0.5 \mathrm{mg} \mathrm{KOH} \mathrm{g}^{-1}$ sample. The effect of process parameters like reaction time, temperature and reactant molar ratio was investigated in non-catalytic esterification of free fatty acids (FFA) in jathropha with methanol. The optimal conditions were found to give a maximum conversion of $95.1 \%$ at $5 \mathrm{hr}$ reaction time (Karna et al., 2016).

There are various ester applications such as in food and beverages, cosmetic and personal care, wastewater management, paper and coating, metal working fluids, rolling oils and synthetic lubricants (Yaakob and Bhatia, 2004). Previous study reported on the use of soyabean-based glycol ester as coalescent aid in water-based paint formulation. The compositions of soyabean-based glycol ester and their physical properties were determined according to the application (Jiratumnukul and
Van Der Mark, 2000). Therefore in this work, the influence of operating condition such as reaction temperature, reactant mole ratio and stirring speed rate for production of diethylene glycol dilaurate in the absence of catalyst were studied.

\section{MATERIALS AND METHODS}

\section{Materials}

Lauric acid (LA) ( $\geq 98 \%$ purity) was obtained from Emery Oleochemical (M) Sdn Bhd, Malaysia. Diethylene glycol ( $\geq 98 \%$ purity) was purchased from Bumi Pharma Sdn Bhd, Malaysia. The reagents were used without any purification and stored as recommended by manufacturers.

\section{Reaction Procedure for Autocatalytic Esterification of Lauric Acid}

LA was reacted with diethylene glycol (DEG) in a $250 \mathrm{ml}$ three-necked flask fitted with a magnetic stirrer, thermometer and a water condenser. The reaction temperature was varied at $150^{\circ} \mathrm{C}, 170^{\circ} \mathrm{C}$, $190^{\circ} \mathrm{C}, 210^{\circ} \mathrm{C}$ to $230^{\circ} \mathrm{C}$ in the absence of catalyst. The LA to DEG molar ratio was set for 1:1, 1:1.5 and 2:1. The experiments were carried out under atmospheric pressure and the stirring speed rate of the solution was varied from 300-1200 rpm. The reactants are mixed and heated to the desired reaction temperature. After reaction, the excess reactants were removed by vacuum distillation.

\section{Analyses and Properties Evaluation of Palm-based Glycol Ester}

The progress of the reactions was monitored by acid value $(\mathrm{AV})$ determination from samples withdrawn every hourly intervals as referred to AOCS Official Method Te1a-64. The percentage of unreacted DEG was measured by the hydroxyl value $(\mathrm{OHV})$ analysis according to AOCS Official Method Cd13-60. The amount of moisture content

TABLE 1. CLASSIFICATION OF SURFACTANT FUNCTION BASED ON HYDROPHILIC-LIPOPHILIC BALANCE (HLB) INDEX

\begin{tabular}{lcl}
\hline \multicolumn{1}{c}{ Solubility characteristic } & HLB index & \multicolumn{1}{c}{ Function } \\
\hline Hydrophobic (oil soluble) & 0 & - \\
& $2-3$ & Anti-foaming agents \\
Water dispersible & $3-6$ & w/o emulsifying agents \\
Hydrophilic (water soluble) & $7-9$ & Wetting and spreading agents \\
& $8-16$ & o/w emulsifying agents \\
& $13-15$ & Detergents \\
\hline
\end{tabular}

Note: Calculation of HLB values of non-ionic surfactants.

Source: Griffin (1954). 
in the product was analysed using Karl Fischer Titrator (Mettler Toledo, C30).

Compositions of monoester and diester were determined using gas chromatography (HP5890, Agilent Technologies, USA), performed using the $30 \mathrm{~m}$ long of capillary column SGE- HT5 equipped with flame ionisation detector (FID). The oven temperature was set initially at $100^{\circ} \mathrm{C}$, held for $5 \mathrm{~min}$, and then increased at $6^{\circ} \mathrm{C} \mathrm{min}^{-1}$ to $350^{\circ} \mathrm{C}$. Helium was used as the carrier gas at a flow rate of $20 \mathrm{ml}$ $\mathrm{min}^{-1}$. Injector temperature was set at $350^{\circ} \mathrm{C}$ with split ratio set at 10: 1. FID was used and temperature was set at $360^{\circ} \mathrm{C}$.

Products obtained were then further characterised using Fourier transform infrared (FTIR Spectrum 100, Perkin Elmer, USA) spectroscopy to determine functional group.
Conformation of molecular in solution can be analysed by Proton nuclear magnetic resonance (400 MHz NMR, JEOL, USA) analysis. Hydrophiliclipophilic balance (HLB) index was determined to predict function of the surface active agent obtained as tabulated in Table 1.

\section{RESULTS AND DISCUSSION}

The autocatalytic esterification reaction to produce DEG dilaurate (DEG-DL) was conducted between DEG and LA as illustrated in Figure 1. Water was produced as by-product along with the formation of DEG monolaurate (DEG-ML). Esterification is a clean process as no chemical catalysts was incorporated.

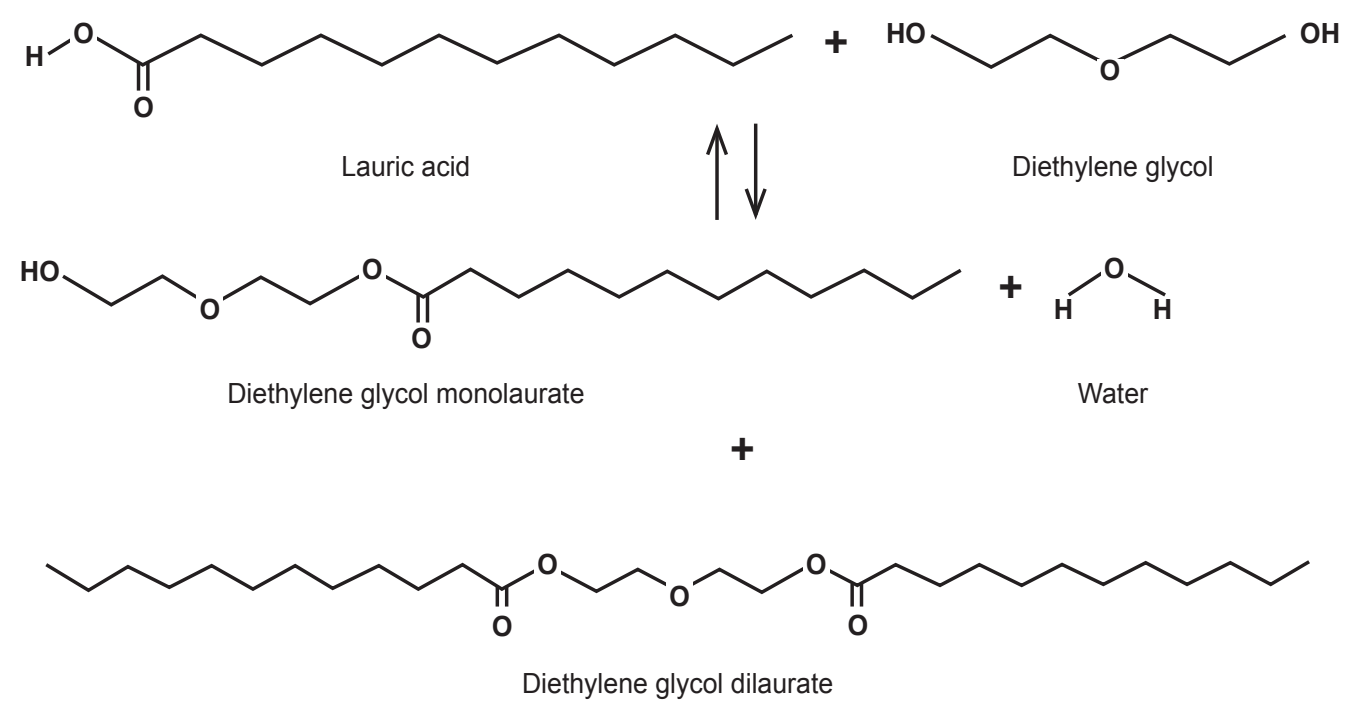

Figure 1. Schematic diagram of stoichiometric esterification between palm-based lauric acid (LA) and diethylene glycol (DEG).

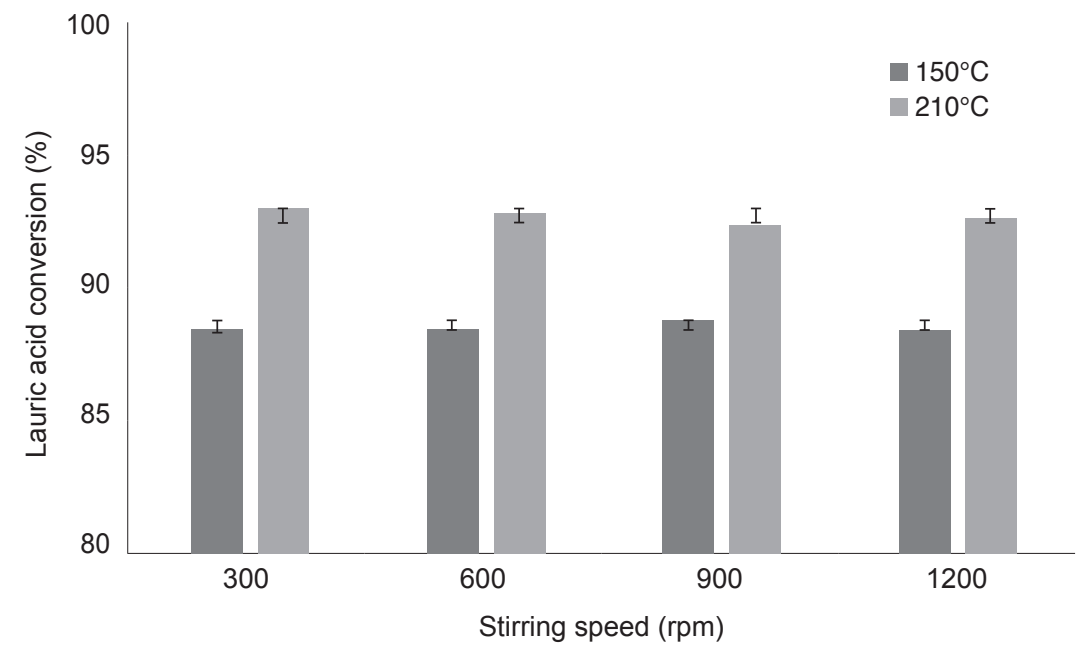

Figure 2. Profile of lauric acid (LA) conversion during autocatalytic esterification of palm-based LA and diethylene glycol (DEG) at different stirring speed and reaction temperature. 


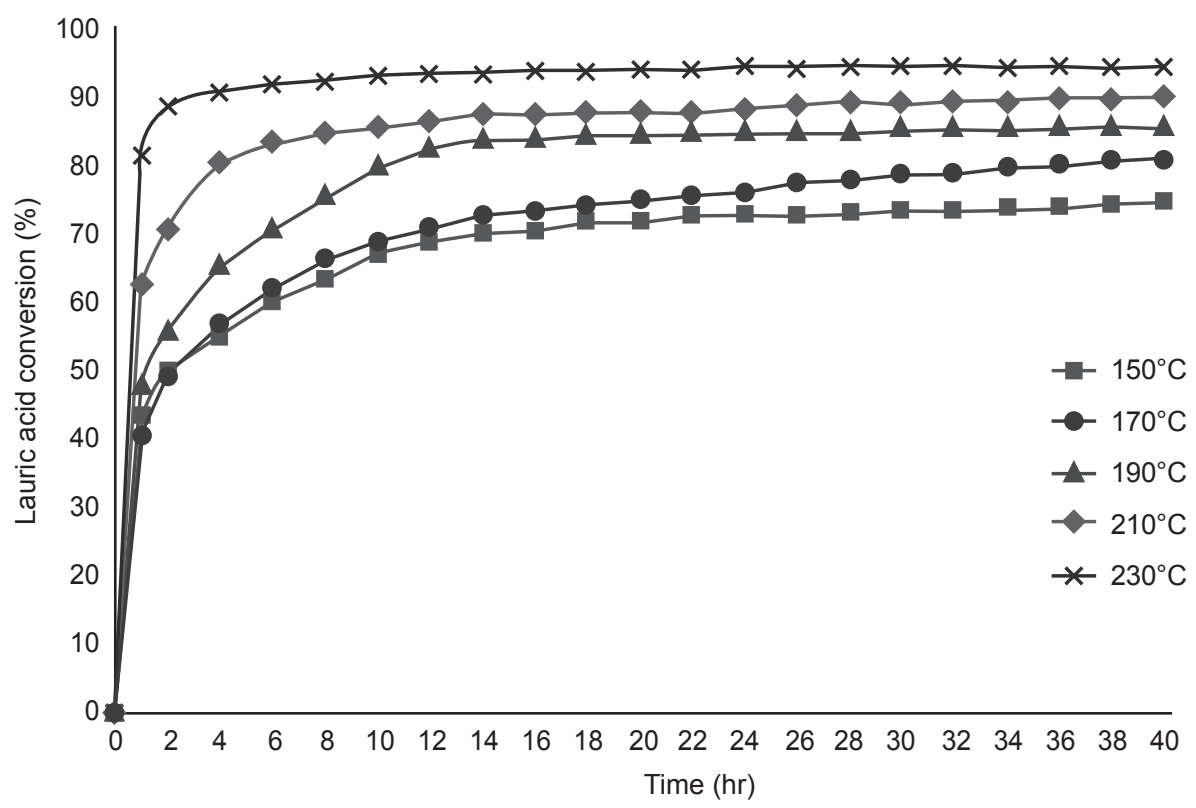

Figure 3. Conversion of lauric acid (LA) over time for esterification of $L A$ and diethylene glycol (DEG) at different reaction temperatures using molar ratio of $L A: D E G=1: 1$ at $300 \mathrm{rpm}$.

\section{Effect of Stirring Speed Rate}

The external mass transfer rate between bulk phases of the reactants will increase by increasing the stirring speed rate. The effect of stirring speed on conversion of LA was investigated. The speed of magnetic stirrer was varied at $300 \mathrm{rpm}, 600 \mathrm{rpm}, 900$ $\mathrm{rpm}$ and $1200 \mathrm{rpm}$ at reaction temperatures of $150^{\circ} \mathrm{C}$ and $210^{\circ} \mathrm{C}$. Based on the conversion trend obtained in Figure 2, there was no influence of reaction rate in stirring speed. At the reaction temperature of $150^{\circ} \mathrm{C}$, the conversion of LA increased slightly from $88.5 \%$ up to $89 \%$ with the increase of stirring speed rate from $300 \mathrm{rpm}$ to $1200 \mathrm{rpm}$. Similar trend was observed when the reaction was performed at reaction temperature of $210^{\circ} \mathrm{C}$.

The conversion of LA was $93.4 \%$ at $300 \mathrm{rpm}$ and not much increase when the stirring speed was varied up to $1200 \mathrm{rpm}$. This indicated that the effect of stirring speed rate on LA conversion was minimal and has no influence on reaction rate. Hence, the optimum stirring speed rate chosen was $300 \mathrm{rpm}$ to ensure complete mixing.

\section{Effect of Reaction Temperature}

The effect of reaction temperature on the esterification was studied at $150^{\circ} \mathrm{C}, 170^{\circ} \mathrm{C}, 190^{\circ} \mathrm{C}$, $210^{\circ} \mathrm{C}$ and $230^{\circ} \mathrm{C}$. Other process parameters were fixed at molar ratio of LA/DEG of 2:1 and $300 \mathrm{rpm}$ as shown in Figure 3. From the plots, it can be observed that the LA conversion increased with temperature. At lower temperature of $150^{\circ} \mathrm{C}$, a minimal conversion was obtained with $72 \%$ LA converted throughout $20 \mathrm{hr}$ duration. After $22 \mathrm{hr}$ reaction, the reaction reached equilibrium with a maximum LA conversion of approximately $74 \%$. A slightly higher conversion was observed when performing the reaction at $170^{\circ} \mathrm{C}$ than that obtained at $150^{\circ} \mathrm{C}$, with maximum conversion of $82 \%$. At temperature of $190^{\circ} \mathrm{C}$, the conversion of LA increased rapidly to more than $80 \%$ within $10 \mathrm{hr}$ reaction and started to plateau after $12 \mathrm{hr}$ reaction course.

Increasing the temperature to $230^{\circ} \mathrm{C}$ resulted in an apparent increased conversion in the beginning with maximum LA conversion of more than $90 \%$ and it approached a plateau after $4 \mathrm{hr}$ reaction time as it reached equilibrium thereafter. Hence, $230^{\circ} \mathrm{C}$ was found to be the best temperature to perform the esterification due to the limitation of the boiling point of DEG reported at approximately $245^{\circ} \mathrm{C}$ in material safety data sheet (MSDS).

\section{Effect of Reactants Molar Ratio}

To study the effect of molar ratio of LA to DEG (LA:DEG) on product composition, three molar ratios were investigated, i.e. 1:1, 1:1.5 and 2:1. Figure 4 shows that as the molar ratio of LA to DEG was increased from 1:1 to 2:1, DEG-ML content decreased and DEG-DL content increased. At molar ratio of $1: 1$, a maximum percentage composition of DEGML obtained was $42.9 \%$ with DEG-DL content of $49.5 \%$. After $20 \mathrm{hr}$ reaction course, the compositions of DEG-ML and DEG-DL content were at constant due to no excess of DEG to forward the reaction. 
AV determined was $8.5 \mathrm{mg} \mathrm{KOH} \mathrm{g}^{-1} \mathrm{LA}$ with conversion of LA was $93.4 \%$. By excessing of DEG in the reaction, the molar ratio of LA:DEG was set at 1:1.5 resulted in the increase of DEG-DL content of $54.9 \%$ with traces amount of unreacted LA detected. Nevertheless, as the LA was fully consumed in the reaction, the excess of DEG content in the product mixture required further step of separation for DEG removal.

The autocatalytic esterification then was performed between two moles of LA reacted with a mole of DEG with the aim to increase the production DEG-DL at lowest AV. The other parameters remained constant. Based on plot of the trend composition of the DEG-ML and DEG-DL as shown in Figure 5, LA was reacted further with DEG-ML to form the DEG-DL. The DEG-ML composition was reduced with the increment of DEG-DL content in the reaction mixture. The observation was also in accordance with the diminishing of DEG detected in the reaction product. The lowest AV measured was $3.09 \mathrm{mg} \mathrm{KOH} \mathrm{g}^{-1} \mathrm{LA}$ and $\mathrm{OHV}$ was $11.8 \mathrm{mg} \mathrm{KOH}$ $\mathrm{g}^{-1} \mathrm{LA}$. A maximum composition of the mixtures of the DEG-ML and DEG-DL obtained were $0.78 \%$ and $97.2 \%$, respectively. Therefore, the molar ratio of $2: 1$ was chosen as the optimum ratio.

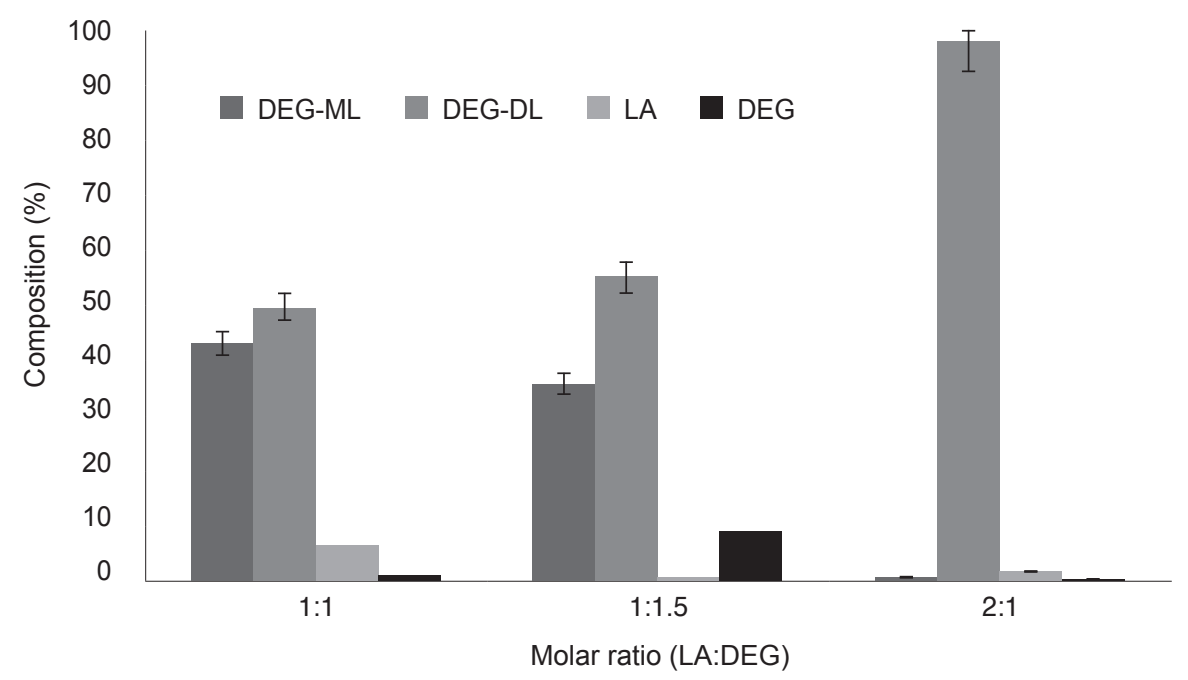

Figure 4. Effect of molar ratio (lauric acid: diethylene glycol) on diethylene glycol (DEG) monolaurate (DEG-ML) and DEG dilaurate (DEG-DL) compositions. Reaction conditions: $230^{\circ} \mathrm{C}, 1$ atmospheric (atm), $300 \mathrm{rpm}$ and duration of $20 \mathrm{hr}$.

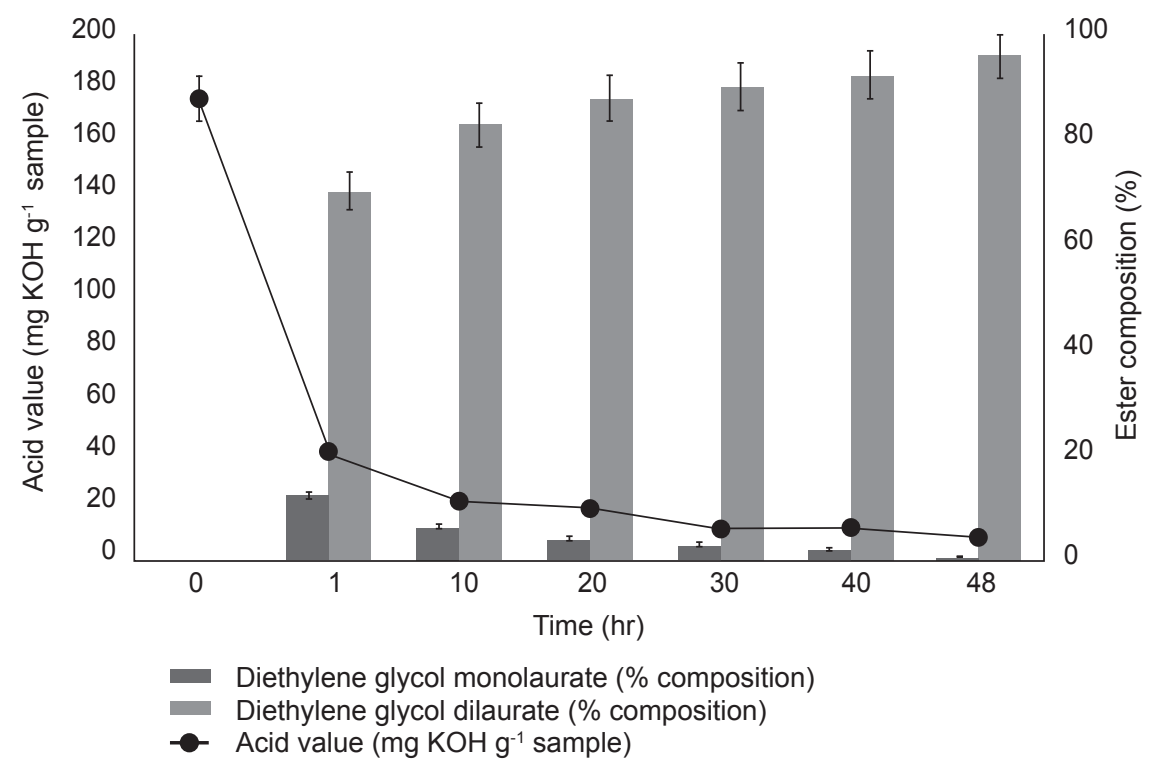

Figure 5. Acid value and product percentage composition profile for self-esterification of 2 moles of lauric acid (LA) and 1 mole of diethylene glycol (DEG) at temperature of $230^{\circ} \mathrm{C}$ for $48 \mathrm{hr}$ reaction time. 


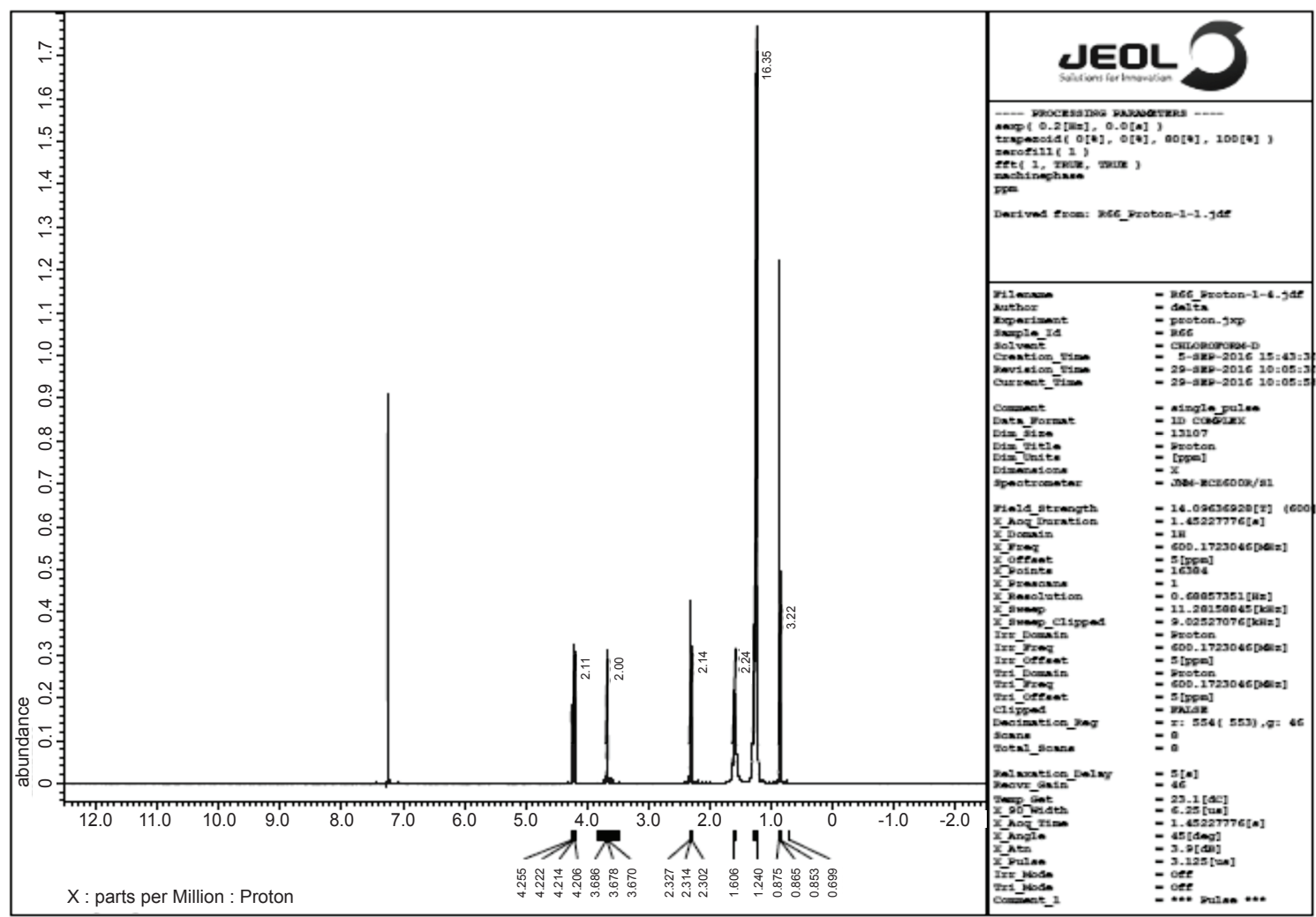

Figure 6. ${ }^{1} \mathrm{H}$ Nuclear Magnetic Resonance (NMR) spectra of palm-based diethylene glycol di-laurate (97.17\% based on GC composition).

\section{Product Characterisation}

The structural study by NMR spectroscopy was performed as shown in Figure 6. DEG-DL with 97.2\% purity was analysed with the proton $\left({ }^{1} \mathrm{H}\right) \mathrm{NMR}$. The $-\mathrm{CH}_{3}$ in the lauric acid portion was referred to the peak at $0.875 \mathrm{ppm}(\mathrm{t}, 3 \mathrm{H})$. The $-\mathrm{CH}_{2}$ - in the lauric acid part was corresponded to the peak at $1.24 \mathrm{ppm}$ $(\mathrm{s}, 16 \mathrm{H})$. There were peaks at $1.61 \mathrm{ppm}(\mathrm{s}, 2 \mathrm{H})$ and $2.31 \mathrm{ppm}(\mathrm{t}, 2 \mathrm{H})$ that belonged to $\mathrm{R}-\mathrm{CH}_{2}-\mathrm{CH}_{2}-\mathrm{COO}-$ group. Another group recognised as $\mathrm{HO}-\mathrm{CH}_{2}-\mathrm{CH}_{2}-$ OOC-R was identified at the peaks at $3.68 \mathrm{ppm}(\mathrm{t}$, $2 \mathrm{H})$ and $4.22 \mathrm{ppm}(\mathrm{q}, 2 \mathrm{H})$.

The functional group analysis of starting materials and DEG-DL produced at different reaction time were investigated. DEG-DL compound obtained showed that, at wavenumber $3346 \mathrm{~cm}^{-1}$ corresponded to a peak of $\mathrm{OH}$ stretching. However, this peak vanished in the DEG-DL spectra. At wavenumber of $1696 \mathrm{~cm}^{-1}$ in the LA spectra revealed carboxylic group stretched and ester group was produced at wavenumber $1737 \mathrm{~cm}^{-1}$. The $\mathrm{C}-\mathrm{O}$ stretching peaks were obtained at wavenumber 1352 and $1429 \mathrm{~cm}^{-1}$.

HLB index calculated for DEG-DL produced was 7.5. The DEG-DL is a self-dispersing nonionic compatible with surface active agents. It is suggested as a water-in-oil or oil-in-water emulsifier with an auxiliary agent. The DEG-DL produced is potentially to be used in textiles, as ingredients in cosmetic formulations, coating and paper defoamer formulations according to the physico-chemical properties tailored to applications.

\section{CONCLUSION}

The autocatalytic esterification of palm-based LA and DEG for the production of diethylene glycol dilaurate (DEG-DL) was investigated. The optimum operating condition was established at temperature of $230^{\circ} \mathrm{C}$ and reactant molar ratio LA to DEG was 2:1, gave LA conversion of more than $90 \%$. The reaction rate was independent of stirring speed rate for this process. Maximum content of DEG-DL obtained was $97.2 \%$ with acid value of $3.09 \mathrm{mg} \mathrm{KOH}$ $\mathrm{g}^{-1}$ LA. This esterification was a clean process as it involved self-catalysed reaction without filtration or purification process. The HLB index calculated was 7.5 and potentially funtioned as emulsifier in various field.

\section{ACKNOWLEDGEMENT}

The authors would like to thank the Director-General of MPOB for permission to publish this article. This study was funded by MPOB (M-RD08010000). 


\section{REFERENCES}

Griffin, W C (1954). Calculation of HLB values of non-ionic surfactants. J. Society of Cosmetic Chemist's, 5(4): 249-256.

Hyun, J C; Jin-Kuk, K; Seok, W H and YeongKoo, Y (2012). Development of a novel process for biodiesel production from palm fatty acid distillate (PFAD). Fuel Process. Technol., 104: 271-280.

Hans, E H; Dirk, E D V; Suhas, A C and Pierre, A J (2004). Esterification and transesterification of renewable chemicals. Top Catal., 27: 1-4.

Jiratumnukul, N and Van Der Mark, M R (2000). Preparation of glycol esters of soybean oil fatty acids and their potential as coalescent aids in paint formulations. J. Amer. Oil Chem. Soc., 77: 691-697.

Jothiramalingam, R and Wang, M K (2009). Review of recent developments in solid acid, base and enzyme catalysts (heterogeneous) for biodiesel production via transesterification. Ind. Eng. Chem. Res., 48: 6162-6172.

Kalaru, S; Lingaiah, N; Sai Prasad, PS; Prabhavathi, D B L A; Prasad, R B N and Venkateswar, S (2009). Influence of carbon chain length and unsaturation on the esterification activity of fatty acids on $\mathrm{Nb}_{2} \mathrm{O}_{5}$ catalyst. Ind. Eng. Chem. Res., 48: 10816-10819.

Kantlehner, W (1991). Comprehensive Organic Synthesis: Selectivity, Strategy and Efficiency in Modern Organic Chemistry. Pergamon Press, Inc., Elmsford, New York. p. 485-599.

Karna, N P R; Tulasi, S V R N; Thella, PK; Satyavathi, $B$ and Chintha, S (2016). Kinetics of non-catalytic esterification of free fatty acids present in jatropha oil. J. Oleo Sci., 65: 441-445.

Kushairi, A; Soh Kheang Loh; Azman, I; Elina Hishamuddin; Meilina Ong-Abdullah; Zanal Bidin Mohd Noor Izuddin; Razmah, G; Shamala Sundram and Ghulam Kadir Ahmad Parveez
(2018). Oil palm economic performance in Malaysia and R\&D progress in 2017. J. Oil Palm Res. Vol. 30 (2): 163-195.

Maeda, H; Joelianingsih, S; Hagiwara, H; Nabetani, Y; Sagara, T H and Soerawidjaya (2008). Biodiesel fuels from palm oil via the noncatalytic transesterification in a bubble column reactor at atmospheric pressure: A kinetic study. Renew. Energy, 33: 1629-1636.

Mazo, P; Rios, L; Diana, E and Marisa, S (2012). Self-esterification of partially maleated castor oil using conventional and microwave heating. Chem. Eng. J., 185-186: 347-351.

Robert, L (1997). Enzyme catalysed esterification. Biotechnol. Adv., 15: 1-15.

Razmah, G (2017). MPOB's role towards competitiveness of Malaysian oleochemicals industry. Oral presentation presented in the PIPOC 2017 International Palm Oil Congress and Exhibition. Kuala Lumpur Convention Centre, Kuala Lumpur.

Yaakob, A Q and Bhatia, S (2004). Esterification of palmitic acid with methanol in the presence of macroporous ion exchange resin as catalyst. IIUM Eng. J., 5: 35-51.

Yamazaki, R; Iwamoto, S; Nabetani, H; Osakada, K; Miyawaki, O and Sagara, Y (2007). Non-catalytic alcoholysis of oils for biodiesel fuel production by a semi-batch process. Japan J. Food Eng., 8: 11-18.

Yujaroen, D; Goto, M; Sasaki, M and Shotipruk, A (2009). Esterification of palm fatty acid distillate (PFAD) in supercritical methanol: Effect of hydrolysis on reaction activity. Fuel, 88: 2011-2016.

Zhong, S; Duan, X; Zhao, J; Wang, X and Jiang, $Z$ (2015). Homogeneous borotungstic acid and heterogeneous micellar borotungstic acid catalysts for biodiesel production by esterification of free fatty acid. Biomass and Bioenergy, 76: 31-42. 